\title{
Web Design and Application Programming Interface (API) Smart Farming Application
}

\author{
Annafi' Franz* \\ Software Engineering Technology, \\ Agricultural Polytechnic of \\ Samarinda, Samarinda, Indonesia \\ annafifranz@gmail.com \\ *Corresponding Author
}

\author{
Eko Junirianto \\ Software Engineering Technology, \\ Agricultural Polytechnic of \\ Samarinda, Samarinda, Indonesia \\ eko.ilkom@gmail.com
}

\author{
Suswanto \\ Software Engineering Technology, \\ Agricultural Polytechnic of \\ Samarinda, Samarinda, Indonesia \\ suswanto.attala@gmail.com
}

Received: 2021-02-05; Revised: 2021-02-23; Accepted: 2021-02-26; Published: 2021-03-14

\begin{abstract}
Agriculture in Indonesia plays a very important role. But the agricultural sector also has a lot of crowds in the process, from the nursery process to the feeding process to the harvesting process, especially when the current Corona pandemic is very influential, for that we need special attention from the parties involved in overcoming the existing problems. In agriculture these processes become more effective and efficient so as to increase the level of productivity of agricultural products. One way to overcome this problem is to involve technology which is currently developing rapidly. The technology that will be built will be able to help the agricultural management process which can be called smart agricultural technology. Technology is able to collect data and present hydroponic plant data during the planting process so that appropriate action can be taken immediately. The technology that will be built in the form of a Web and API (Application Programming Interface) in smart farming applications is expected to be able to make the planting management process more effective and efficient.
\end{abstract}

Keywords - Technology, Data, Web, API, Smart Farming

\section{INTRODUCTION}

Agriculture is one of the most important economic sectors in Indonesia. However, the Center for Indonesian Policy Studies (CIPS) estimates that agricultural production will fall $1.64 \%$ to $6.2 \%$ due to disruption of supply chains affected by the Corona pandemic. In addition, production also experienced a decline due to a decrease in workforce in the agricultural sector by 1.63 $4.87 \%$ due to the corona outbreak (Alika, 2020). But on the other hand, during the corona pandemic, as at present, the information technology sector, especially digital, which requires internet access, has experienced a rapid increase, it has been proven that digital businesses such as YouTube, zoom, goggle meet have experienced a very significant increase in users, especially when the government implements the WFH (Work From Home) policy, where all activities are carried out from the house (CNN Indonesia, 2020).

To help overcome the problem of declining agricultural production, it seems necessary to include the role of technology in terms of agricultural production. The combination of technology and agriculture is commonly called smart farming. Smart farming technology will regulate and monitor the process from planting to harvest so that it is hoped that the production process will be more efficient and effective so that it can increase agricultural production.

Currently, one of the technologies that is currently developing quite rapidly is the web. With the web, all data and information can be channeled effectively and efficiently and can load and display various information that can be accessed from various devices. In addition, the development of smart phone technology (smartphone) has also begun to make people dependent on these devices. The dependence of the Indonesian people on a smartphone can't be separated from the conveniences offered by the development of this device. Along with the development of these smartphone devices, the development of applications that further support the use of smartphones with the features offered is also accompanied. Moreover, analysts predict that the smartphone market in Indonesia will grow by $9 \%$ by 2020 (Pratnyawan, 2020). The development of a technology that supports applications on smartphones is now starting to increase in its development, especially on smartphones with the Android operating system, from a standalone application to an application that can connect with other applications via a global network. This technology is known as the Web Service API (Application Programming Interface) which is able to provide services to different devices such as smartphones and laptops (Javatpoint, 2018).

Based on problems in agriculture and its relation to current technological developments, it is necessary to create a web-based information system to store and record all the data obtained during the planting process, the maintenance process to the crop harvesting process. The system created is also equipped with an API to support related applications.

\section{LITERATURE REVIEW}

\section{A. Scientific Study}

The following describes several related studies regarding the API web service: 
a) Nina, Rachman, \& Surahman (2020), Artificial Intelligence-Based Agricultural Information System (E-Tandur). In this study, an agricultural information system based on the Internet of Things (IoT) is used as a medium to increase the precision of the quality of agricultural products. By integrating information systems into the agricultural sector, it will increase the quality, resilience and make the cost of agricultural production effective.

b) Saputri \& Mulyono (2019), Analysis and Design of a Management Information System for Web-Based Harvest Data Reporting at the Jambi Province Food Crops Agriculture Service. The information system built supports the process of recording, processing, searching for data to the process of presenting reports. So, the information system built will be very supportive in presenting information that supports decision making.

c) Rahayu, Cahyana, \& Cahyana (2019), Designing a Web-Based Agricultural Product Information System with a Unified Approach. This information system is designed to make it easier for farmers to inform agricultural products directly to consumers.

d) Aprini (2019), Designing a Web-Based Agricultural Product Marketing Information System in Pagar Alam City. In this study, namely designing an information system that can be used to promote, inform quickly, precisely and accurately the agricultural products in Pagar Alam City. So that the agricultural products of Pagar Alam City can be recognized by people outside the city of Pagar Alam or the wider community, so that they can attract consumers to make purchases.

e) Elmayati \& Hazilawati (2019), Design of an SMS Gateway-Based Information System for Agricultural Product Extension in Musi Rawas District. By utilizing the SMS Gateway technology, farmers in the Musi Rawas district will find it easier to obtain information about agricultural crop cultivation procedures, agricultural commodity prices and agricultural issues. In addition, the implementation of agricultural extension activities will be easier and able to reach remote areas.

f) Perkasa \& Setiawan (2018), Community Data Web Service Development Using REST API with Access Token. In this study, the application built provides a web service data for the community to create and register job seeker cards using data from the Population and Civil Registry Service. This application is able to provide and facilitate many parties, such as data administrators to monitor data usage, employee registration in data input, and people can register independently.

g) Setiawan, Eosina, Primasari, \& Ridwan (2018), Information System for Medicinal Plants Management (SITANO). In this study, the information system was made web-based to facilitate the management of medicinal plants. The information system built contains a lot of information starting from nursery activities, plant care, to administrative and financial reports. Making the medicinal plant information system turns out to make the management of medicinal plants more effective and efficient.

h) Wulandari, Ugiarto, \& Hairah, (2017), Information System for Herbal Medicines. This information system contains information about herbal medicinal plants, the substances contained in these plants, properties and methods of processing these plants so that they can be used to become herbal medicinal plants. The information system that was built aims to facilitate the public in searching for information on herbal medicine.

i) Sundari (2016), Web-Based Information System for Community Health Center Services. This patient service information system is designed to improve manual systems that are slow so that services become ineffective and efficient, so that a computerized information system is built, making it easier for the Public Health Center to process patient data and patient medical records into reports.

j) (Prasetyo, Fauzi, Supratman, \& Murti, 2016), WebBased E-Farming Information System Design System to Determine the Feasibility Level of Harvest in the Agricultural Sector. This information system is designed to be able to provide an early detection statement of the occurrence of a level of feasibility or inappropriate yields in the agricultural sector.

\section{B. WEB}

Definition of the website according to the Cambridge dictionary (Cambridge Dictionary, n.d.): a set of pages of information on the internet about a specific subject, which have been published by the same person, company, or organization, and often contain images, videos, and sounds.

A website is a collection of interrelated, publicly accessible Web pages that share a single domain name. Websites can be created and maintained by individuals, groups, businesses or organizations to serve various purposes. Together, all publicly accessible websites constitute the World Wide Web (Technopedia, n.d.).

Website is a web page that is interconnected which generally contains a collection of information in the form of text data, images, animation, audio, video or a combination of all that is usually made for personal, organization and company (Indowebsite, n.d.). Picture 1 shows the information and features contained in the website.

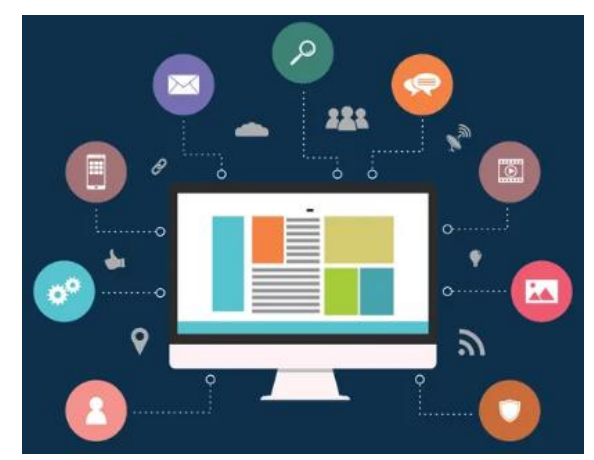

Picture 1 Website information and features (acodez.in) 


\section{API (Application Programming Interface)}

API stands for Application Programming Interface, and allows developers to integrate two parts of an application or with different applications simultaneously. API consists of various elements such as functions, protocols, and other tools that allow developers to create applications. The purpose of using the API is to speed up the development process by providing separate functions so that developers don't have to build similar features. Implementation of the API will be very felt if the desired feature is very complex, of course it takes time to create something similar to it. For example: integration with a payment gateway. There are various types of system APIs that can be used, including operating systems, libraries, and the web. Web API is accessed via the HTTP protocol, this is a concept not a technology. We can create a Web API using different technologies such as PHP, Java, .NET, etc. For example, the Rest API from Twitter provides read and write access to data by integrating Twitter into our own application (Sandi, 2017).

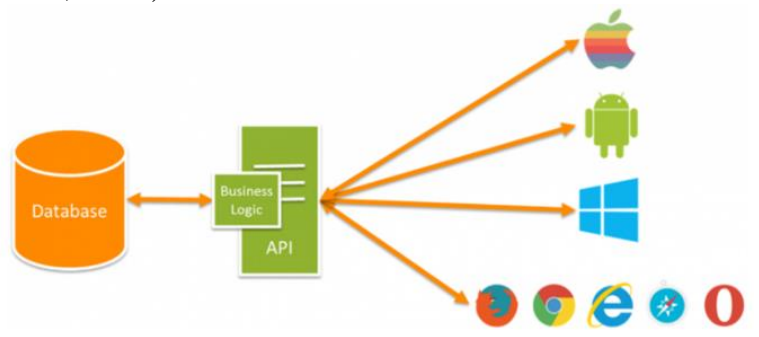

Picture 2 API Scheme (codepolitan.com)

Web Service is software that is created to bridge machine to machine in a network or a service that allows interaction and communication between different systems (interoperability) in a network. Web services store data with an XML standard so that this results in the sharing of communication between different operating systems, compilers, and platforms. And in the process, web services do not need a GUI because web services work in logical functions and request data. So basically Web Service is a method that bridges between 2 machines or 2 different systems to be able to communicate on a network while API is a collection of libraries or functions in making software to be able to communicate between 2 different software (Arni, 2018).

\section{III.REASEARH METHODS}

The methodology to be used in this research is by using the Waterfall method which is part of the Software Development Life Cycle (SDLC) model. The stages of this model start from the system analysis stage, system design and so on to the system maintenance stage. The cycle of the waterfall model can be seen in Picture 3.

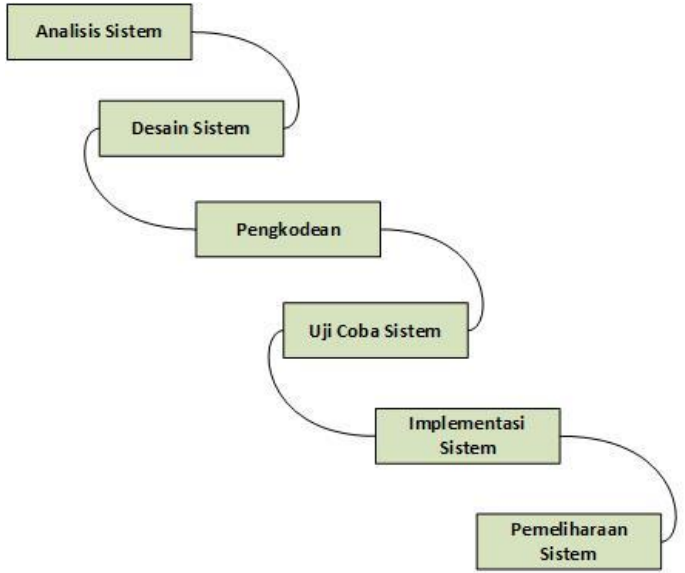

Picture 3 Schematic of the Waterfall model

\section{System Analysis}

At the system analysis stage, an analysis of the problems and systems to be built is carried out. Analysis is needed to determine system requirements, starting from the form of data to be processed by the system to analyzing system requirements in building APIs so that they can become data bridges for various devices.

\section{E. System Design}

At this stage, the system planning is carried out according to the system requirements that have been determined at the system analysis stage. The system to be built is the web and API. The web will receive data from hydroponic plants, while the data received will be displayed on the web and stored in the database as data that will be given to android devices through the help of an API. The flow of the system is as shown in Picture 4.

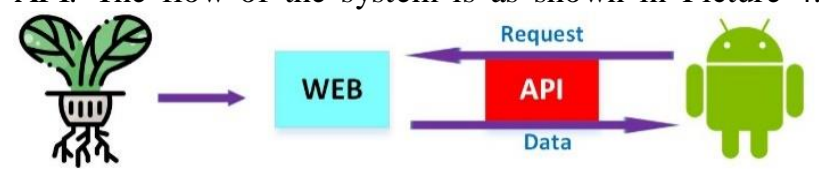

Picture 4 System Flow

\section{F. Program Coding}

At the coding stage, namely creating a web and API using a programming language based on the system design that has been made.

\section{G. System Trial}

At the system trial stage, an experiment is carried out whether the web created can receive, store and display data received from hydroponic plants properly. In addition, testing is also carried out whether the API created can provide data to Android devices according to the request.

\section{H. System Implementation}

The implementation stage is the stage for implementing a system that is made ready for use. The system is implemented according to plan, namely receiving data from hydroponic gardens and displaying it on the web and storing it in a database server. The system also provides data to the android device according to the data request from the android device. 


\section{System Maintenance}

System maintenance is necessary to ensure that the system continues to run properly. At the system maintenance stage, it is necessary to pay attention to the data received, stored, displayed and given accordingly.

\section{IV.RESULTS AND DISCUSSIONS}

Here are tenants or registered users using the API feature to collect data from hydroponics as shown in Picture 5.

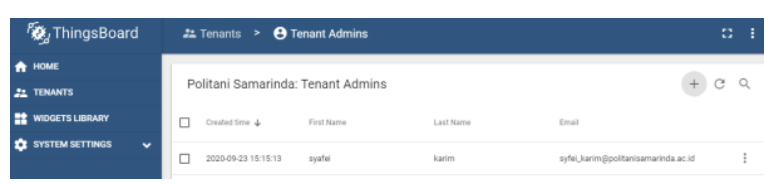

Picture 5 User

Registered users have four types of data, namely data on temperature, humidity, $\mathrm{pH}$ and water nutrition. The following Picture 6 is a web view of the environmental temperature of hydroponic plants

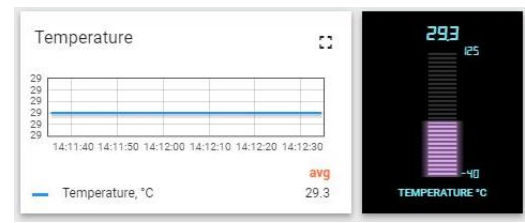

Picture 6 Temperature

The following Picture 7 is a web view of humidity from the hydroponic plant environment.

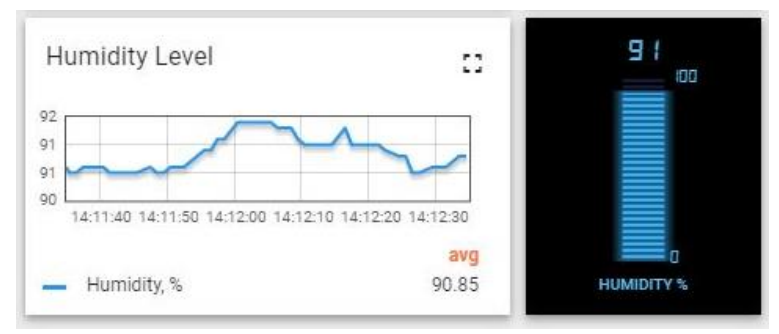

Picture 7 Humidity

The following Picture 8 is a web view of the $\mathrm{pH}$ of the hydroponic plant environment.

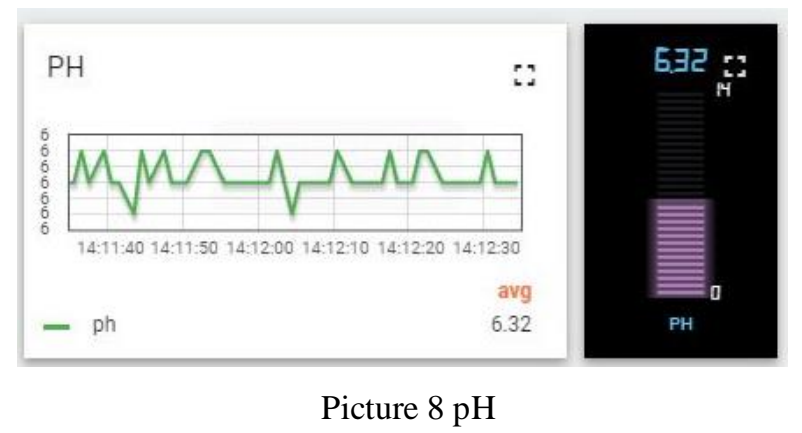

The following Picture 9 is a web view of the $\mathrm{pH}$ of the hydroponic plant environment.

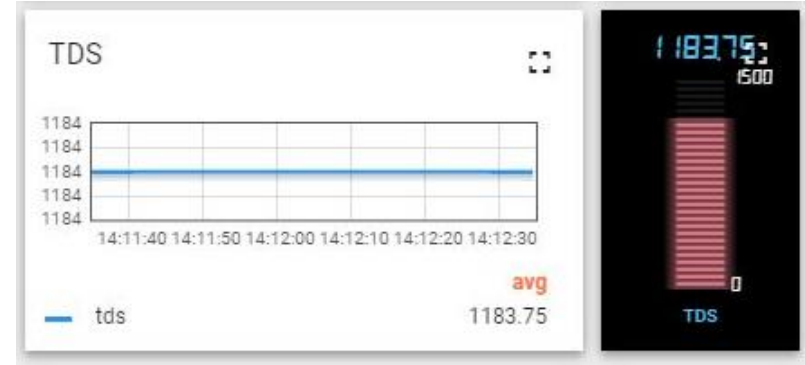

Picture 9. TDS

Of the four types of data received, namely temperature, humidity, $\mathrm{pH}$ and water nutrition, they can be displayed properly on the website. In addition, systems with API features can also provide data to Android devices as shown in Picture 10.

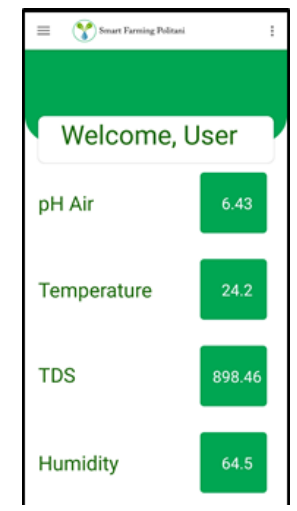

Picture 10 Display Data on Android Devices

\section{CONCLUSION}

From the results of the discussion carried out in the research "Designing Web and API (Application Programming Interface) Smart Farming Applications" it can be concluded that the web and API in the smart farming application can receive, store and display hydroponic plant data and provide that data on an android device. . This achievement will facilitate monitoring of hydroponic plants as part of a smart farming system.

\section{REFERENCES}

Alika, R. (2020, March 3). Produksi Pertanian Diperkirakan Turun 6,2\% Terimbas Pandemi Corona. Retrieved from Katadata: https://katadata.co.id/happyfajrian/berita/5e9a41 f6c9500/produksi-pertanian-diperkirakan-turun62-terimbas-pandemi-corona

Aprini, N. (2019). PERANCANGAN SISTEM INFORMASI PEMASARAN HASIL PERTANIAN BERBASIS WEB DI KOTA PAGAR ALAM. Jurnal Informatika Lembah Dempo , 13-24.

Arni, U. D. (2018, February 2). Perbedaan Api dengan Web Service. Retrieved from Garuda Cyber Indonesia: https://garudacyber.co.id/artikel/284perbedaan-api-dengan-web-service

Cambridge Dictionary . (n.d.). Cambridge Dictionary . Retrieved from Cambridge Dictionary : 
https://dictionary.cambridge.org/dictionary/engli $\mathrm{sh} /$ website

CNN Indonesia. (2020, September 4). Pengguna Internet Kala WFH Corona Meningkat 40 Persen di RI. Retrieved from CNN Indonesia: https://www.cnnindonesia.com/teknologi/20200 408124947-213-491594/pengguna-internet-kalawfh-corona-meningkat-40-persen-di-ri

Elmayati, \& Hazilawati. (2019). PERANCANGAN SISTEM INFORMASI PENYULUHAN BUDIDAYA HASIL PERTANIAN BERBASIS SMS GATEWAY DI KABUPATEN MUSI RAWAS. Jurnal Teknologi Informasi Mura, 118124.

Indowebsite. (n.d.). Website. Retrieved from Indowebsite: https://www.indowebsite.co.id/website/

Javatpoint. (2018). Web API. Retrieved from Javatpoint: https://www.javatpoint.com/web-api

Nina, A., Rachman, O., \& Surahman, R. (2020). Sistem Informasi Pertanian Berbasis Kecerdasan Buatan (E-Tandur). Jurnal Manajemen Informatika (JAMIKA), 1-10.

Perkasa, M. I., \& Setiawan, E. B. (2018). Pembangunan Web Service Data Masyarakat Menggunakan REST API dengan Access Token. ULTIMA Computing, 19-26.

Prasetyo, N. D., Fauzi, W. A., Supratman, D., \& Murti, S. (2016). Perancangan Sistem Informasi EFarming Berbasis Web Untuk Mengetahui Tingkat Kelayakan Panen Pada Sektor Pertanian. Seminar Nasional Aplikasi Teknologi Informasi (SNATi), 7-12.

Pratnyawan, A. (2020, January 1). Pasar Smartphone Indonesia 2020 Diprediksi Tumbuh 9 Persen, Ini Kata Analis. Retrieved from hitekno.com: https://www.hitekno.com/gadget/2020/01/01/13 1500/pasar-smartphone-indonesia-2020diprediksi-tumbuh-9-persen-ini-kata-analis

Rahayu, S., Cahyana, R., \& Cahyana. (2019). Perancangan Sistem Informasi Hasil Pertanian Berbasis Web Dengan Unified Approach. Jurnal Algoritma, 100-107.

Ramadhani, P. I. (n.d.).

Sandi, A. (2017, November 16). Mengenal Apa itu Web API. Retrieved from Codepolitan: https://www.codepolitan.com/mengenal-apa-ituweb-api-5a0c2855799c8

Saputri, V., \& Mulyono, H. (2019). Analisis Dan Perancangan Sistem Informasi Manajemen Pelaporan Data Hasil Panen Berbasis Web Pada Dinas Pertanian Tanaman Pangan Provinsi Jambi. Jurnal Manajemen Sistem Informasi, 114125.

Setiawan, A., Eosina, P., Primasari, D., \& Ridwan, T. (2018). Sistem Informasi Pengelolaan Tanaman Obat (SITANO). Prosiding SINTAK, 182-188.

Sundari, J. (2016). Sistem Informasi Pelayanan Puskesmas Berbasis Web. Indonesian Journal on Software Engineering, 44-49.
Technopedia. (n.d.). What does Website mean? Retrieved from Technopedia: https://www.techopedia.com/definition/5411/we bsite

Wulandari, Z., Ugiarto, M., \& Hairah, U. (2017). SISTEM INFORMASI OBAT-OBATAN HERBAL. Prosiding Seminar Ilmu Komputer dan Teknologi Informasi, 227-234. 